\title{
Networking among rural tourism entrepreneurs
}

\author{
H. Farrell ${ }^{1}$, G. Bosworth ${ }^{2}$ \& R. Newbery ${ }^{3}$ \\ ${ }^{I}$ Department of Tourism, University of Lincoln, UK \\ ${ }^{2}$ Enterprise Research and Development Unit, University of Lincoln, UK \\ ${ }^{3}$ Centre for Rural Economy, Newcastle University, UK
}

\begin{abstract}
In this paper we explore the role of in-migrant owners of small tourism firms in promoting entrepreneurship and developing competition in the tourism economy of Northumberland. We hypothesise that through a combination of extra-local networks and local embeddedness these business owners are not only succeeding themselves but they are stimulating other local businesses by increasing local trade, heightening competition and raising standards and aspirations.

The role of in-migrants is further explored in theoretical terms. Their networking behaviour and the importance of what Saxena terms "relational capital" in the process of integrating rural tourism into the wider local economy is of particular interest given that some of these business owners are recent arrivals into the area. Of further interest are the links between place, community and local products, services and activities. The ability of in-migrants to create a sense of place and as well as embedding their businesses within the local economy is discussed.

Keywords: business networks, lifestyle businesses, rural development, entrepreneurship, counterurbanisation, embeddedness, social capital.
\end{abstract}

\section{Introduction}

Tourism contributes some $£ 12 \mathrm{bn}$ per annum to rural economies and supports an estimated 380,000 jobs (Ilbery et al. [2]) but rural locations attractive to tourists are not necessarily attractive locations for entrepreneurial endeavour and economic dynamism. Rural tourism is dominated by microbusinesses and many of these are not the main income source for their owners (Getz and Peterson [3]). 
As such they are marginal both spatially and economically leading us to explore some of the measures taken by rural tourism entrepreneurs to overcome these challenges, focusing on networking behaviour and the institutions and spaces that facilitate such interactions.

A range of personal and business networks are highly valuable for the transfer of knowledge and opportunities among rural tourism firms. Furthermore, the relationships developed can help firms to become embedded, encourage cooperation and generate an entrepreneurial milieu. As small tourism firms are not always the most entrepreneurial in terms of growth aspirations and innovation (Bosworth and Farrell [4]; Morrison et al. [5]), we explore the positive and negative outcomes attributed to their activity, based on interviews with indigenous and in-migrant owners in Northumberland and research into four tourism-dominated business networks in the same region.

Rural areas provide distinct challenges for entrepreneurs given their remoteness from larger markets and skilled labour and the low density of businesses. Attractive rural locations provide alternative motives for potential entrepreneurs, often less driven by growth and profitability and more by personal and lifestyle choices (Bosworth [6]). As such, new forms of rural enterprise have focused on exploiting market niches and commodifying certain features of rurality. While the benefits to the local economy have been identified, the focus on niche provision and the prevalence of small firms leads to questions about the scope of tourism enterprises. This is especially true where tourism firms are run by "lifestyle entrepreneurs", defined as tourism business owners who are actively seeking a different type of lifestyle. They may have migrated to the destination specifically for this purpose, but may already live there. Their motivations centre on quality of life and the local environment, and they are not therefore as profitoriented as other entrepreneurs (Morrison et al. [5]).

\section{The role of networks in rural tourism businesses}

The main problem is that there is no single definition of a 'network'. Murdoch, alone, describes horizontal and vertical [7] and economic and social [8] networks, each with different significance. Other proponents of networks as drivers of productivity and competitiveness (Rosenfeld [9]; Chell and Baines [10]; Johannisson et al. [11]) and as potential vehicles for rural development (Lowe et al. [12]; Murdoch [7]) are also unable to agree on a unique definition. Egocentric and sociocentric networks (Johannisson et al. [11], hard and soft networks (Rosenfeld [9]; Petrou et al. [13]) strong and weak ties (Chell and Baines [10]; Saxena and Ilbery [14]) or associative and communal relations (Tiepoh and Riemer [15]) are all concepts related to networks of people but none provide a single, over-riding definition.

Looking at the etymology of the term (Harper [16]), uses the simple definition, "an interconnected group of people", and emphasises the significance of connections and communication. This highlights the importance of the structure as well as the nodes and the nature of their interconnectivity, providing a basis to consider different forms of networks and their significance for tourism 
businesses. A wealth of advantages have been linked to networks including the motivation of entrepreneurship (Copus and Skura [17]), time and money saved in information gathering (Malecki and Oinas [18]), support for nascent small business (Davidsson and Honig [19]), innovation (Camagni [20]) access to training (Bennett and Errington [21]) and providing a firm "with its 'distinctive capabilities' that help it to create and add value" (Malecki [22, p. 173]). Totterman and Sten [23] found that formal support groups can facilitate access to other business networks, implying that cumulative benefits can accrue.

The values of networks for businesses appear to be two-fold. As well as practical issues, there are less tangible benefits associated with social capital. Social capital refers to "features of social organization, such as networks, norms and trust, that facilitate coordination and cooperation for mutual benefit" and it "enhances the benefits of investment in physical and human capital" (Putnam $[24$, p. 1]). In this respect, we are not looking at the quantifiable benefits of additional trade or cost savings but the social values of mutual understanding, cooperation and a sense of shared identity. As such, localities with high levels of social capital are more likely to reap greater benefits in using human and physical capital and citizens in these localities enjoy a better quality of life. By bringing people together, whether towards business or social ends, networks are able to augment social capital development. As Maskell ([26, p. 111]) states, "social capital is accumulated within the community through processes of interaction and learning". As a resource, it is therefore augmented not diminished through use (Westlund and Bolton [27]). Relational capital therefore has the potential to generate further cooperation and help stimulate entrepreneurial development (Saxena [1]).

Perhaps the most effective working definition of social capital is provided by The Performance and Innovation Unit [28] who state that "social capital consists of the networks, norms, relationships, values and informal sanctions that shape the quantity and co-operative quality of a society's social interactions" (p5, emphasis added). This reinforces the intangible quality of social capital as it is not simply networks but something that shapes or facilitates co-operation through networks. In other words, it is not just about whether individuals interact but whether the collective society in question provides the right opportunities and structure to enable fruitful interaction.

\section{Methodology}

The research is set in the North of England and combines interviews with a sample of tourism firms and analysis of four business networks in rural Northumberland. While the broader rural economy of the area has been well researched (e.g. Raley and Moxey [29]; Thompson and Ward [30]) the tourism sector has not been studied separately, despite making up some $30 \%$ of rural microbusinesses in the region.

Tourist numbers to the region have been growing and the average length of stay has also been increasing (One North East [31]). Previous research has shown that just over $20 \%$ of business owners in this sector had other 
employment and almost $80 \%$ of hospitality businesses were registered at the owner's home address demonstrating that these businesses do not operate in isolation from other aspects of their owners' lives. Also, over $70 \%$ of business owners in this sector had moved into the area (Raley and Moxey [29]) and, with in-migrant business owners being more growth oriented (Bosworth and Farrell [4]), this influenced the sampling of a mix of local and in-migrant businesses.

Face to face interviews were carried out with the owners of 16 businesses; six bed and breakfasts, two holiday-cottages, a caravan park, three tea-rooms, two pub/restaurants a village stores and an art and craft gallery. Biographical interviews were used to provide a detailed description of the development of individuals' businesses and a semi-structured questionnaire enabled the interviewer to engage with each unique story through follow-up questions to identify the value of other individuals and networks throughout the account.

As part of a wider study into rural business associations in the North East of England, four local tourism networks were surveyed during 2009. These were formally constituted as partnerships or associations and ranged in size from 22 to 106 members. They were loosely focused on rural service centres (3 market towns and a collaboration between 2 villages), with membership dispersed in the surrounding districts. A census was sent out by post to all members of the networks achieving a 51\% response rate (122 respondents). The questionnaire explored the costs and benefits of membership and captured social, economic and demographic data on the respondent and their business.

\section{Tourism entrepreneurs and networking}

The literature identified different forms of networking providing different benefits to businesses. The findings begin with an overview of the four business networks highlighting a range of motivations for participation and associated benefits. Interview analysis then explores the value of networking and is divided into two sections to draw out the differences between formal or organised business networking and less formal social or community-based relationships. One specific feature of networking among tourism firms is that it seldom involves the end customers (i.e. tourists) enabling us to differentiate broader networking activity from more direct marketing activity.

\subsection{Tourism networks}

The four tourism networks in the study were voluntary associations operating under a regime of private law. They were formed by individuals for reasons relating to the promotion of the business and rural area; being described as a private response to peripherality, since "nobody else will do it for us" (Member Gilsland and Greenhead) and due to perceptions of "Government hostility to rural areas" (Member Haltwhistle Tourism Association) with a corresponding poor public provision of tourism services and area promotion. They have nominal annual subscription fees from $£ 25$ to $£ 56$. 
Over $70 \%$ of respondents are aged $50+$ and $77 \%$ of members are in-migrants. Members appear quite integrated with the local area, with $97 \%$ of them making local purchases (defined as within a 30 radius) for the business in the past 12 months. Indeed, nearly half the businesses made at least $90 \%$ of purchases within the local area. Tourism businesses account for $88 \%$ of members (a mix of guest house, hotel, public house and restaurants), with $8 \%$ running local shops and $4 \%$ in agriculture. Over $48 \%$ of respondent businesses have no employees, indicating that many of these businesses are secondary to the owners' main pursuits. Over $64 \%$ of members reported an increase in profits during the last 5 years and $46 \%$ consider the business to be growing (with $48 \%$ indicating a steady state).

The smaller associations meet only during the 'off-season' and due to strong links with agriculture the last meeting before the summer precedes the onset of lambing time (resulting in a median of 4.5 meetings a year). These associations have a variety of aims and they meet to exchange local knowledge, such as the times of various events, swap marketing literature, form responses to threats to local tourism (such as wind farms or open-cast mining) and discuss approaches to improving the marketing of the local area. Methods used to promote the area include a basic cooperative web-site and an information 'drop-off', where members' brochures and a locally sponsored tourist map are dropped off to tourist information offices in neighbouring towns and cities.

The larger networks meet twice a year and mainly focus on the production of a cooperative web-site. Network membership has specific rules and members must provide cross-links from their own web-site to the networks in a reciprocal arrangement; resulting in a high search engine ranking for tourism searches within the district. Members post details of their business and accommodation providers must have an annual inspection by Visit Britain, providing evidence of their ranking on the web-site and maintaining quality standards.

All networks provide a mechanism (formal or informal) for members to check the availability of their fellow members' accommodation in the situation where they are fully booked - keeping trade within the area. They are also reported as being particularly useful for new members, typically newcomers to the tourism industry, as they are very useful sources of 'free advice' on what is necessary to survive and prosper in the area.

\subsection{Attitudes towards business networking}

The examples above are all forms of organised business networks and the opportunities for cooperation, knowledge exchange, joint marketing and the establishment of new businesses are all benefits recognised in the wider literature on business networking. When asked about networking, the vast majority of individuals associated the term with these organised forms of activity and the general attitude was more often a negative one. A publican's reaction was, "I curl my nose up really." By contrast, the same individual explained that "it's very important to support the local guesthouses because they do a lot of marketing and if we've got our brochures there it helps them no end knowing they can send people for a meal here and they know they can rely on us." 
People's attitudes are affected by both the people they want to cooperate with as well as the structure and setting of a particular network.

A caravan site operator has few connections to the local community as his customers are not local and the service he provides is much less personal. As such, his response to a question about networking was, "I've heard it, what does it mean?" The owner of a holiday cottage spoke of the high level of materials received through the post, saying, "I'm so cynical, when these glossy things come, I just throw them in the bin. I'm a small concern, it's a different ball game, but if there's something I miss out on, I get narked!' In these cases independence outweighs the need to engage with local business organisations and friends and family are the core sources of support.

As well as an inherent independent attitude among rural business owners, this is compounded by a sense of marginalisation from some larger organisations that do not always cater for their needs. A Bed and Breakfast operator said "So much networking tends to be organised in Newcastle...They couldn't even tell you where this village is. " Another noted that the local Tourist Information Centres were not helpful to their village saying that they are "missed out by all of them...this is why we need to help each other out because we don't get referrals". Having acted on this, they have a strong, but largely informal local network of bed and breakfast operators who exchange referrals. Another very local group has flourished in part as a response to being marginalised, with one member saying, "I think everybody feels that the village needs to get itself more noticed."

Where business owners do participate in formal networks, they tend to take a clear business decision, assessing the likely benefits that they can obtain. A tearoom owner described how she joined a regional network specifically to get a credit card machine at a reduced rate but has no other involvement. Another couple explained that they had never run their own business before so, "Business Link were very helpful... when we put in for the shop I had to do a business plan and that was very involved...At the time it was a lot of work, but looking back it gave us a lot of ideas".

The examples in Section 4.1 illustrated that business networks are more highly valued by business owners new to an area and this is supported by individual interviews. Where less formal local networks take time to develop, these organisations provide access to information and support that can be essential in establishing a business. As such, where incomers have positive experiences, they are more likely to reciprocate their time and effort into supporting these networks. A bed and breakfast operator who is on the board of an area partnership explained that it is not about helping her own business "it' $s$ more the other way round; it helps any board that I sit on that I run my own business." While acknowledging that she benefits from up to date information, this was clearly a secondary motivation for participation. The opportunity to support others and therefore collectively support the development of tourism in the local area was the central motivation.

A similar distinction can be observed with incomers' attitudes towards inspectors. Local owners expressed suspicion that inspectors will give away their 
secrets and resentment that they are invading their personal space by judging their accommodation and service. Two both used the term "nitpickers" to describe them. Incomers had more positive experiences, in one case commenting on the helpful advice they had received and another commented, "We're very lucky because by and large inspectors come here who I've got to know, I'd say they are very switched on ...they understand the reality of running a business".

The sense that networking is a professional, business activity was clearly illustrated by an incomer who explained the value of her relationship with Business Link and the courses she has attended. This sense of investing time and effort for measurable returns was further highlighted by her reaction to a less formal group who "squabble about and don't get on with what they should be getting on with, they talk about how they should be running the meeting...I'm not very patient with that sort of thing, I think 2 hours of my time I could be spending doing something more productive so I voted with my feet and didn't go back."

This very pragmatic approach to formal networking is not unique to tourism businesses but the implication is that networks need to offer a clear incentive to attract members. A majority of very small businesses in the tourism sector means that networks have the opportunity to draw in a critical mass for external marketing but this does not require high levels of interpersonal engagement. As such, more innovative approaches to provide useful information, advice and linkages are thought to be essential for successful and vibrant network groups. In particular, the participation of businesses that link to core tourism activities without necessarily being defined as tourism businesses can add a valuable dimension to support business development.

\subsection{Non-business networking}

For some rural businesses the best networking can happen when the business owner is totally unaware that they are engaging in networking activity. When asked about networking, a hotel and pub owner replied, “"Networking...networking just means with the computers." Subsequently though, she revealed that she values feedback from customers, supports local events in the community and often speaks with her competitors in the village. For the pub trade, these are all essential for the service she provides but if this became a more formalised process, it may be less effective.

The overlap between business and social networks is apparent in many ways, confirming Granovetter's argument that "the behavior and institutions to be analyzed are so constrained by ongoing social relations that to construe them as independent is a grievous misunderstanding" (Granovetter [32, pp. 481-482]). A good example comes from a bed and breakfast owner saying, "I go to evening classes, I'm making stain glass panels now, I went to an evening class where I could put something back into the house, I'd love to go to an upholstery one as well. " Running a small tourism business is more than just a form of income but also a lifestyle choice, and moreover, a lifestyle choice where a desire to deliver a high quality of service and a responsibility to represent the broader locality motivates good business practices. The difference is that these are personal and 
independently minded choices rather than following mainstream business theories.

The informal group of bed and breakfast owners mentioned in 4.2 who exchange referrals was instigated by incomers who, in part saw it as an opportunity to be socially accepted into the local area. In another fairly informal village network, the organiser explained, "it's good because its links with local people who live and work in the community, because we're all busy businesses, it gives us a chance to meet with one anther as well." As an informal, friendly group, new business owners have been welcomed as much through a sense of a social responsibility to support their venture as through any sense that it is important for the businesses to benefit directly.

The direct benefits derived from informal networks were discussed by all interviewees to some extent. One commented on how she entered selfemployment for the first time, saying, "I knew the lady in the tea-room in was nearing retirement so I spoke to her and she let me work there for a summer before I took it over to get the feel of it. She was supportive and watched over $u s^{\prime}$. As an older person, embedded in the local community this support was invaluable to developing the confidence to run the business - a level of confidence that saw her expand the business significantly in the coming years.

Given the nature of many tourism businesses, trust is highly valued. This leads many business owners to rely on personal contacts for part time staff rather than advertising more widely. In a similar vein, a cottage owner explained that she can always leave keys with neighbours if they are away and expecting tourists to arrive. Business owners also spoke of the importance of good tradespeople and accountants in more remote communities. One spoke of her accountant: "you just hand everything over to her.". The accountant was recommended by a nearby farmer and now the bed and breakfast owner has recommended the same person to the local shopkeeper so once again social capital facilitates not only new business but initiates relationships that are already enriched with trust. Such practical arrangements are often taken for granted but without access to social capital, business operations would be much more complicated.

While social and business networks overlap substantially, there is evidence that incomers keep a greater degree of separation, at least in the early years. For example, while locals consistently expressed preferences to support local businesses and use local produce wherever possible, in-migrants took time to evaluate the cost and quality of local products. Another example of this more guarded approach comes from a pub/restaurant owner who commented about a business in the same village with whom they have a very good relationship. She said, "I'll send people across there but I've never eaten there myself so I'll not recommend, I'll just says that here's another place in the village that does food." Where there is a risk that lower quality produce or poor recommendations will affect the business, the balance between social and economic motivations is brought back into focus and the behaviour of individuals is affected.

In the main though, the benefits of strong social networks appear to outweigh any costs. Whether it is built around the knowledge that people will "always go 
that extra mile" to help out because they are regular customers or whether it is purely an exchange of ideas and "gossip" over a cup of tea, business owners speak very positively about the value of close friends in the running of their businesses, and in the rural tourism sector, these tended to be closely linked to the local area given that they all lived and worked within the same broader community.

\section{Conclusions}

The paper has highlighted contrasts in networking behaviour among in-migrant and local business owners. It also notes the particular importance of networking in rural tourism businesses. Networking provides benefits beyond business development and financial gain and this is particularly important for lifestyle businesses. It is posited that human and social capital are of greater importance to lifestyle businesses because maintaining a lifestyle is the driving force.

Networks help develop a sense of local identity and embedding rural tourism businesses in the local area further creates a sense of "authenticity" which is so often sought in tourist interactions with host or destination. Embedding provides opportunities for the business owner, in the shape of increased availability of local knowledge and trade links. However, as Saxena and Ilbery [25] have noted, embedded networks are not inevitably beneficial for all. There are instances noted above in which in-migrants felt excluded from participation in the informal networks more often populated by local members.

The contrasting ability or inclination to network amongst in-migrant and locals has been noted. However, both groups form networks. In-migrants are more likely to be members of "hard" or formal networks at first, although they often integrate into other forms of network later. This indicates weaker emotional connections to networks in the early years and more reliance instead on formal memberships controlled by rules of participation. These types of network are usually more costly and less durable or long-lived (Petrou et al. [13]). In our study, more formal networks had a rule-based membership, met less frequently, offered less chance to build personal relationships, and focused on the promotion of businesses and on ensuring quality. Participation in formal networks was seen as a business decision, based on assessments of likely benefits. Locals were more likely to be involved in informal networks of friends and family although they may not consider these relationships to form a network. These are less demanding of resources and more focused on intangible benefits such as sharing knowledge and experience. These networks are also more longlived. Non-participation in networks, where it occurred, was mainly because of their desire to maintain independence, rather than any sense of exclusion.

Saxena [1] concluded that the relational or social capital generated from these interactions were the greatest benefits of networks in rural tourism. In the Northumbrian study sites, networks met for knowledge exchange, sharing marketing materials, mobilising against perceived threats, and planning improvements in promotional activities. However, informal networks had formed in response to being left out of larger urban-based networks. Informal 
networks were set up for exchange referrals or sharing information. There were also overlaps between business networking and social networks, especially among lifestyle business owners. Networks offered means of social involvement and, for in-migrants, a route to acceptance in their new communities. Indeed, inmigrants were generally well-integrated with the local area, and although they were more likely to value formal networks for information sharing and support at first, they participated fully in them. Furthermore, participation in networks need not be a business decision in its narrowest sense. We found that participation could be motivated by a sense of community responsibility rather than business benefit.

Some of these conclusions pose further questions. For example, local business owners are often less entrepreneurial in their business behaviour (Bosworth and Farrell [4]), preferring to retain the status quo in the business rather than innovate. As such, in-migrants were often the drivers of change, countering Saxena's [1] interpretation of relational capital which suggests non-migrants should be better placed to foster an entrepreneurial approach based on access to the informal networks which provide the support and confidence to make changes in their own businesses. The key to understanding the potential benefits of networking for the rural tourism economy lies in the degree of overlap between innovative or entrepreneurial in-migrants and local business owners with access to local knowledge and local social or relational capital. In particular, the dynamics of these relationships, the places they occur and the causes and pace of their development should be the focus for ongoing research.

\section{References}

[1] Saxena, G., Relationships, networks and the learning regions: case evidence from the Peak District National Park. Tourism Management, 26(2), pp. $277-$ 289, 2005.

[2] Ilbery, B., Saxena, G., \& Kneafsey, M., Exploring Tourists and Gatekeepers' Attitudes Towards Integrated Rural Tourism in the EnglandWales Border Region. Tourism Geographies, 9(4), pp. 441-468, 2007.

[3] Getz, D. \& Petersen, T., Growth and profit-oriented entrepreneurship among family business owners in the tourism and hospitality industry. International Journal of Hospitality Management, 24(2), pp. 219-242, 2005.

[4] Bosworth, G. \& Farrell, H., Tourism Entrepreneurs in Northumberland: The Role of In-Migrants. Forthcoming.

[5] Morrison, A., Carlsen, J., \& Weber, P., Lifestyle Oriented Small Tourism [Lost] Firms and Tourism Destination Development. In: Tourism and Hospitality Research, Training and Practice: Proceedings of the 18th Annual Council for Australian University Tourism and Hospitality Education Conference, Gold Coast, Australia, 11th-14th February 2008

[6] Bosworth, G. Entrepreneurial in-migrants and economic development in rural England. PhD Thesis, University of Newcastle, 2009. 
[7] Murdoch, J., Networks - a new paradigm of rural development? Journal of Rural Studies 16, pp. 407-419, 2000.

[8] Murdoch, J., Networking rurality: emergent complexity in the countryside (Chapter 12). Handbook of Rural Studies, ed. P. Cloke, T. Marsden, \& P. Mooney. Sage, London, 2006.

[9] Rosenfeld, S., Does Co-operation Enhance Competitiveness? Assessing the impacts of inter-firm collaboration. Research Policy 25, pp. 247-263, 1996.

[10] Chell, E. \& Baines, S., Networking, entrepreneurship and microbusiness behaviour. Entrepreneurship and Regional Development, 12, pp. 195-215, 2000.

[11] Johannisson, B., Ramirez-Pasillas, M. \& Karlsson, G., The institutional embeddedness of local inter-firm networks: a leverage for business creation. Entrepreneurship \& Regional Development 14, pp297-315, 2002.

[12] Lowe, P., Murdoch, J. \& Ward, N., Networks in rural development: beyond exogenous and endogenous models (Chapter 5). Beyond Modernisation: The Impact of Endogenous Rural Development, ed. J. D. Van der Ploeg \& G. Van Dijk Van Gorcum, Assen, The Netherlands, 1995.

[13] Petrou, A., Pantziou, E.F., \& Dimara, E. Resources and Activities Complementarities: the Role of Business Networks in the Provision of Integrated Rural Tourism. Tourism Geographies, 9(4), pp. 421-440, 2007

[14] Saxena, G. \& Ilbery, B. Developing integrated rural tourism: Actor practices in the English/Welsh border. Journal of Rural Studies, In Press, Corrected Proof.

[15] Tiepoh, M. Geepu Nah \& Reimer, B., Social capital, information flows, and income creation in rural Canada: a cross-community analysis. Journal of Socio-Economics 33, pp. 427-448, 2004.

[16] Harper, D. Online Etymology Dictionary. Accessed 13 February 2008 at: www.etymonline.com

[17] Copus, A. \& Skuras, D., Business Networks and Innovation in Selected Lagging Areas of the European Union: A spatial Perspective. European Planning Studies 14(1), pp. 79-93, 2006.

[18] Malecki, E. J. \& Oinas, P., Making Connections: Technological learning and regional economic change. Ashgate Publishing, Aldershot, 1999.

[19] Davidsson, P. \& Honig, B., The role of social and human capital among nascent entrepreneurs. Journal of Business Venturing 18, pp. 301-331, 2003.

[20] Camagni, R., Local 'milieu', uncertainty and innovation networks: towards a new dynamic theory of economic space. Innovation Networks, ed. R. Camagni, Belhaven Press, London, 1991.

[21] Bennett, R. J. \& Errington, A., Training and the small rural business. Planning Practice and Research 10(1), pp. 45-54, 1995.

[22] Malecki, E. J., Technology and Economic Development: The dynamics of local, regional and national competitiveness. Longman, Harlow, 1997.

[23] Totterman, H. \& Sten, J., Start-ups: Business Incubation and Social Capital. International Small Business Journal 23(5), pp. 487-511, 2005. 
[24] Putnam, R., The Prosperous Community: Social Capital and Public Life. The American Prospect, No.13 (Spring 1993) pp. 35-42, 1993.

[25] Saxena, G. and Ilbery, B. Integrated rural tourism a border case study. Annals of Tourism Research, 35(1), pp. 233-254, 2008

[26] Maskell, P., Social Capital, Innovation, and Competitiveness. Ch 6 in Social Capital, Critical Perspectives edited by S. Baron, J. Field \& T. Schuller. Oxford University Press, 2000.

[27] Westlund, H. \& Bolton, R., Local Social Capital and Entrepreneurship. Small Business Economics 21(2), pp. 77-113, 2003.

[28] Performance and Innovation Unit, Social Capital: A Discussion Paper, 2002.

[29] Raley, M \& Moxey, A Rural microbusinesses in North East England: Final Survey Results. Centre for Rural Economy, University of Newcastle, 2000

[30] Thompson, N. \& Ward, N. Rural Areas and Regional Competitiveness. Centre for Rural Economy, Newcastle University, 2005

[31] One NorthEast Northumberland Rural Accommodation-Challenges and Opportunities. Unpublished data from One NorthEast Regional Tourism Team, 2008.

[32] Granovetter, M., Economic Action and Social Structure: The Problem of Embeddedness. American Journal of Sociology 91(3), pp481-510, 1985. 